\title{
Exploring Students' Difficulties in Comprehending Exposition Text Towards POE Strategy
}

\author{
Ratna Nery ${ }^{1 *}$ and Fitri Novia ${ }^{2}$ \\ ${ }^{1}$ English Language Education Study Program at FKIP Islamic University of Ogan Komering Ilir Kayuagung, South \\ Sumatera 30618, Indonesia \\ ${ }^{2}$ English Language Education Study Program at FKIP Islamic University of Ogan Komering Ilir Kayuagung, South \\ Sumatera 30618, Indonesia \\ *Corresponding author. Email: ratnanery110578@gmail.com
}

\begin{abstract}
Reading is an important skill that students need to comprehend and interpret the content of an English text. Teaching reading at the junior high school level aims to improve students' comprehension skills. The exposition text is one of the genres listed in the English curriculum for junior high school. It is also one of the more challenging genres for learners to grasp when it comes to text comprehension. The aim of this study was to discover students' difficulties in comprehending exposition text based on their reading comprehension level as determined by Barret's Taxonomy.This study was descriptive qualitative. The participant consisted of 42 students from Ponpes Bait Qur'an Kayuagung.The reading test in the form of multiple choice with 40 questions of exposition text was applied in this study as an instrument. Based on Barret's Taxonomy analysis, students' problems with exposition comprehension were linked to literal comprehension, reorganization, inference, evaluation, and appreciation. Hence, the POE strategy is recommended to address students' difficulties in comprehending exposition text.
\end{abstract}

Keywords: exposition text, POE strategy, reading comprehension, students' difficulties

\section{INTRODUCTION}

Reading is a great accomplishment when learners consider the amount of levels and components that must be grasped. Reading is regarded as a necessary skill since it provides students with knowledge, beliefs, and enjoyment. Reading may allow students to have access to information about the language that is required for readers [1]. The main purpose of reading is to gain knowledge from the content being read The learner must be able to interpret the text correctly and extract meaning from it in order for something to be accomplished. Students must not only understand the meaning of written material in English during reading activities, but they must also use the information they have to draw critical and creative conclusions, explore into the author's intentions, and analyse the thoughts offered in the text [2]. Reading is the active process of extracting meaning from printed words or linguistic symbols in written material. The reader must comprehend the content of the text so that they can get information and knowledge. The reader integrates her or his language abilities with a background of global knowledge to comprehend the message during this procedure [3].
Futhermore, students need to comprehend the content of a passage so that they can get open their mind and get a lot information. Reading comprehension is the understanding of the information between word and sentences used to obtain the information from a reading passage through reading comprehension skills [4]. The competence to read, particularly the ability to read foreign language materials, brings up new knowledge and opportunities. This enables pupils to get knowledge, enjoy themselves, and participate in a variety of activities that the global society undertakes as a result of information obtained through reading [5].

Otherwise, reading comprehension is considered difficult to understand English text. Reading comprehension is a challenging and active process of understanding of text [6]. Reading comprehension is a complex process of understanding meaning that is heavily influenced by the reader's ability to complete the reading assignments [7]. Some studies found that students could read fluently but could not understand what they were reading. [8]. Complexity of the reading material, environmental impacts, anxiety during reading comprehension, interest and motivation, decoding, and word recognition speed are all aspects that affect reading comprehension skills.. Based on Nation, reading 
comprehension is a difficult skill that requires a variety of cognitive and linguistic processes to complete [9]. This complexity can be described as a combination of two abilities: decoding and language comprehension.

Moreover, there are many factors that make difficult reading comprehension. Students have three problems in learning reading comprehension [10]. First, Students regard new words as a significant barrier to understanding a text. Learners must recognize the terms or vocabulary employed in the paragraph in order to understand the content of the text. Second, students frequently feel dissatisfied with their ability to recollect information they have just read. They need to be able to hold information in working memory for long enough for it to be processed thoroughly, yet many of them lack this ability. Third, students read very little or none at all. This is seen to be a significant barrier to students' comprehension of a written text. Finally, another aspect that has a significant impact on reading comprehension is the type of text. It is regarded as a significant difficulty. Some passages are simple to understand, while others are really tough. Many EFL students have trouble completing reading comprehension problems in English textbooks. There are two parts to this issue. First, the questions may not be appropriate for the learners' levels. Second, the proportions of the questions may not be appropriate for their levels. A textbook written for elementary school students, for example, may have an excessive number of cognitively challenging questions [11].

In reading, the text is very necessary. Many researchers emphasized the value of text for readers, as reading is impossible without it. Exposition, argumentation, report, process, narrative, and descriptive texts are examples of different types of text. Exposition text is one of the texts that should be taught. Exposition text is written by an author who is attempting to inform and describe an event that has occurred in his or her environment [12]. An expository text is one in which the authors attempt to inform, explain, depict, or persuade the reader. Exposition text intends to describe the knowledge and experience of the author obtained from literature or field studies with the aim of increasing the reader's insight and knowledge about something [13]. The exposition text is also one of the difficulties' genres that students learn in understanding text. It caused that the students had difficulties in composing of exposition text, especially in identifying thesis statement, arguments, and reiteration of this text.

In addition, the exposition text questions were developed using Barrett's Taxonomy to test students' comprehension. To stimulate and help students comprehend the reading passage related to the final English test, reading comprehension questions covering all levels of questions based on Barrett's taxonomy were needed [14]. This reading comprehension taxonomy is divided into five types. Literal comprehension, reorganization, inferential comprehension, evaluation, and appreciation are the five skills. According to each category contained and covered, this taxonomy is ordered from easy to difficult depending on the degree of competence [15]. The purpose of this study was to investigate students' difficulties in comprehending exposition text based on their reading comprehension level as determined by Barrett's Taxonomy.

\section{METHOD}

The design of this research was a descriptive qualitative research. The participant consisted of 42 students from Ponpes Bait Qur'an Kayuagung.The reading test in the form of a multiple choice with 40 questions of exposition text was applied in this study as an instrument. Barret's Taxanomy analysis was used to analyze the data. Percentage was used to run the data.

\section{RESULT AND DISCUSSION}

Based on the analysis of Barret's Taxonomy, the assessment of reading comprehension questions consisted of literal reading, reorganization, evaluation, appreciation, and inferential comprehension category. It was discovered that $25,78 \%$ of students answered the questions in the literal reading category, there were $27,96 \%$ of students who responded to the reorganization category questions, there were $24,66 \%$ of students who responded to the evaluation category questions, there were $23,68 \%$ of students that responded to the category of appreciation, and there were $18,11 \%$ students that responded to the category of inferential comprehension.

In summary, students got difficulties in answering questions about literal reading, reorganization, evaluation, appreciation, and inferential comprehension. It happened because students lack of vocabulary so that they did not understand the meaning and content of passages. As the result, most of the students failed to answer the questions about inferential comprehension. It meant that they got difficult to understand the text. It suggested that teacher can use POE as strategy to solve students' problem in reading comprehension. Students can apply the POE strategy to reflect on their experiences and understanding of a subject before making a prediction about the outcome of an experiment and discuss it with a classmate [16]. Following up on the discussion with observations and then scientific explanations of the results, students get a greater understanding of the subject.

\section{CONCLUSION}

Based on Barret's Taxonomy analysis, it was found that there were $25,78 \%$ students who answered the questions about literal reading category, there were $27,96 \%$ students who answered the questions about reorganization category, there were $24,66 \%$ students who answered the questions about evaluation category, there were $23,68 \%$ students who answered about appreciation category, and there were $18,11 \%$ students who answered questions about inferential comprehension category. Hence, students got difficulties in answering questions about literal reading, reorganization, evaluation, appreciation, and inferential comprehension. It was recommended to use POE 
strategy because POE (Predict, Observe, Explain) strategy is very effective in diagnosing students' understanding of science and students' completeness level so it has implications for curriculum development, teacher s' development, and students' promotion and understanding [17].

\section{REFERENCES}

[1] A. Maram and M. Farrah, "Eighth Grade Textbook Reading Comprehension Questions and Barrett's Taxonomy: Teachers' Perspectives at Hebron District," Hebron Univ. Res. J., vol. 14, no. 1, pp. 229-260, 2019, [Online]. Available: http://www.hebron.edu/journal.

[2] F. A. Sholihah, "The effectiveness of reading, encoding, annotating, and pondering (reap) strategy in improving students' reading skill," Ju-ke, vol. 1, no. 2, pp. 59-65, 2017.

[3] I. F. Wahyuni, "The assessment of Indonesian EFL students' reading comprehension ability using Reading Evaluation and Decoding System (READS)," UAD TEFL Int. Conf., vol. 2, p. 240, 2021, doi: 10.12928/utic.v2.5766.2019.

[4] D. Sapitri, F. Novia, and Rachmanita, "AN ANALYSIS OF STUDENTS' DIFFICULTIES IN COMPREHENDING NARRATIVE TEXT," Lang. Educ. Journal, vol. 5, no. 2, pp. 103-112, 2020.

[5] R. Ganie, . D., and R. Rangkuti, "Reading Comprehension Problems on English Texts Faced By High School Students in Medan," KnE Soc. Sci., vol. 2019, pp. 684-694, 2019, doi: 10.18502/kss.v3i19.4896.

[6] G. Viii et al., "Improving Students ' Reading Comprehension By Using Reciprocal Teaching

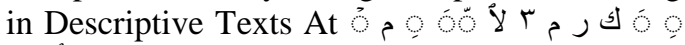

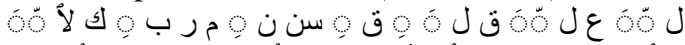

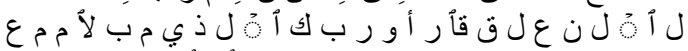

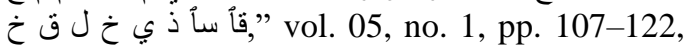
2019.

[7] Y. Mohd Yussof, A. Rasid Jamian, S. Roslan, Z. A. Z. Hamzah, and M. Kamarul Kabilan, "Enhancing Reading Comprehension through Cognitive and Graphic Strategies: A Constructivism Approach," Procedia - Soc. Behav. Sci., vol. 64, pp. 151-160, 2012, doi: 10.1016/j.sbspro.2012.11.018.

[8] Y. C. Lah and N. H. Hashim, "The Acquisition of Comprehension Skills among High and Low Achievers of Year 4 to 6 Students in Primary School," Procedia - Soc. Behav. Sci., vol. 114, pp. 667-672, 2014, doi: 10.1016/j.sbspro.2013.12.765.

[9] K. Nation, "Children's reading difficulties, language, and reflections on the simple view of reading," Aust. J. Learn. Difficulties, vol. 24, no. 1 , pp. 47-73, 2019, doi: 10.1080/19404158.2019.1609272.

[10] I. Shehu, "Reading Comprehension Problems
Encountered by Foreign Language Students, Case Study: Albania, Croatia," Acad. J. Interdiscip. Stud., no. March 2015, 2015, doi: 10.5901/mjss.2015.v4n1s1p91.

[11] N. Adli and A. Mahmoudi, "Reading Comprehension Questions in EFL Textbooks and Learners' Levels," Theory Pract. Lang. Stud., vol. 7, no. 7, p. 590, 2017, doi: 10.17507/tpls.0707.14.

[12] N. Azizah, R. Hayati, and O. Fadloeli, "Improving the Students' Reading Comprehension of Analytical Exposition Text By Using Think-Pair-Share (Tps)," Proj. (Professional J. English Educ., vol. 2, no. 6, p. 904, 2019, doi: 10.22460/project.v2i6.p904-912.

[13] S. M. Sigalingging, "Teaching Reading Comprehension of Narrative," vol. 6, no. GENRE Journal of Applied Linguistics, 2017.

[14] D. N. Rahma, "An Analysis of Reading Comprehension Question Made by English Teacher at SMAN 2 Sidoarjo Based on Barret's Taxonomy," in iNELTAL, 2019, no. 2014, pp. 47-55.

[15] A. Göçer, "The Assessment of Turkish Written Examination Questions Based on the Text in Accordance with the Barrett 's Taxonomy," Int. J. Lang. Educ. Teach., vol. 3, pp. 1-16, 2014.

[16] N. H. Hussain, R. Ali, H. N. Haron, and K. R. Salim, "Predict-Observe-Explain Tasks Using Simulation to Assist Students ' Learning in Basic Electric Circuits," Proc. IETEC'13 Conf., no. November, 2013.

[17] J. S. Hilario, "The use of Predict-ObserveExplain-Explore (POEE) as n New teaching strategy in general chemistry-laboratory," Int. J. Educ. Res., vol. 3, no. 2, pp. 37-48, 2015, [Online]. Available: http://www.ijern.com/journal/2015/February2015/04.pdf. 